\title{
TEOLOGI DAMAI AGAMA ISLAM, HINDU, DAN KRISTEN DI PLAJAN PAKIS AJI JEPARA
}

\section{PEACEFULL THEOLOGY OF ISLAM, HINDU, AND CHRISTIAN RELIGION IN PLAJAN PAKIS AJI JEPARA}

\author{
Ahmad Saefudin \\ Universitas Islam Nahdlatul Ulama Jepara \\ Jl. Taman Siswa No. 9 Pekeng Tahunan Jepara \\ Email: ahmadsaefudin@unisnu.ac.id \\ Fathur Rohman \\ Universitas Islam Nahdlatul Ulama Jepara \\ J1. Taman Siswa No. 9 Pekeng Tahunan Jepara \\ Email: fathurrohman@unisnu.ac.id
}

Naskah diterima tanggal 21 Juli 2019, Naskah direvisi tanggal 21 Agustus 2019, Naskah disetujui tanggal 30 Oktober 2019

\begin{abstract}
Abstrak
Penelitian ini berusaha mengungkap relasi tokoh agama Islam, Hindu, dan Kristen di Desa Plajan Kecamatan Pakis Aji Kabupaten Jepara sebagai upaya pengejawantahan teologi damai. Dalam prosesnya, peneliti terlebih dahulu mendeskripsikan relasi tokoh agama dan persepsi mereka tentang teologi damai. Penelitian termasuk penelitian lapangan (field research) melalui pendekatan qualitative research. Peneliti menggunakan teknik observasi peran serta, wawancara mendalam, dan dokumentasi. Observasi peran serta dilakukan untuk menyelami persepsi tokoh agama Islam, Hindu, dan Kristen tentang konsep perdamaian perspektif agama. Sedangkan wawancara dilakukan dengan berdialog langsung dengan aktor-aktor kunci seperti kiai atau ustad, pendeta, dan agamawan Hindu selaku agen perdamaian. Sedangkan teknik dokumentasi dilakukan dengan cara menelusuri dokumen-dokumen terkait, khusunya surat edaran dari Pemerintah Desa Plajan tentang ajakan mempraktikkan teologi damai. Ternyata, media silaturahmi antar kelompok elite agamawan merupakan salah satu faktor penting berkembangnya relasi damai. Bagi orang Islam, teologi damai tersebut mengacu kepada doktrin Alquran, misalnya QS. al-Baqarah: 256 yang mengajarkan setiap muslim untuk saling menghormati dan respect terhadap umat agama lain. Perspektif Hindu, teologi damai direpresentasikan oleh ajaran tat twam asi (larangan bertikai, menghindari pertengkaran dengan tetangga, dan jika dicubit merasa sakit, maka tidak boleh mencubit orang lain), cung taka (menghindari nalar truth claim), vasudhaiva kutumbakam (tidak mudah terpancing provokasi), om shanti shanti shanti om (menciptakan iklim perdamaian), dan óm swastyastu (kegiatan doa bersama). Sedangkan praktik teologi damai agama Kristen ditunjukkan melalui sikap rendah hati terhadap agama lain, menjauhi watak pendendam, dan menjaga masjid saat umat muslim menunaikan shalat Idul Fitri dan Idul Adha.
\end{abstract}

kata kunci: teologi damai, islam, hindu, kristen

\begin{abstract}
This study aims to uncover the relation of Islamic, Hindu, and Christian religious leaders in Plajan Village, Pakis Aji, Jepara as an effort to embody peaceful theology.. The researcher described the relations between religious leaders and perceptions of peaceful theology. Research is qualitative research by field research. The researcher used participant observation, in-depth interviews, and documentation. The friendship media between religious elite groups was an important factor in developing peaceful relations. For Muslims, it is in line with Qur'an doctrine, like at Surah al-
\end{abstract}


Baqarah verse 256 to respect each other. The peaceful theology of Hindu is represented in tat twam asi teachings (avoiding fighting and quarrels), cung taka (avoiding the truth claim), rationalvasudhaiva kutumbakam (not provoked easily), om shanti shanti shanti om (creating peace climate), and swastyastu óm (prayer activities). Whereas the practice of peaceful theology of Christianity is demonstrated through humble towards other religions, avoiding vengeful character, and helping prayers Eid al-Fitr and Eid-alAdha.

keywords: peacefull theology, islam, hinduism, christianity.

\section{PENDAHULUAN}

A dagium tentang agama ibarat pedang bermata dua memang ada benarnya. Satu sisi, agama diinterpretasikan sebagai sumber perdamaian. Pada sisi yang lain, bisa jadi agama ditafsirkan sebagai ideologi yang memperbolehkan jalan kekerasan. Secara teoretis, agama dan kekerasan merupakan dua entitas yang saling bertentangan (Schumann, 2015), namun narasi konflik, perselisihan, pertentangan, permusuhan, perang, bahkan pembunuhan hampir selalu ada di dalam kitab-kitab kanonik. Alquran, misalnya, sebagai kitab suci bagi umat Islam menyitir istilah-istilah alkhasm, al-mukhashamah (bermusuhan), ikhtilaf (berselisih), tanazu' (pertentangan), dan al-qital, al-harb (perang) sebagai representasi gesekan teologis dan kekerasan agama (Mustaqim, 2014). Perspektif Kristen, kisah Kain dan Habel cukup menjadi bukti konkret bahwa agama bisa ditafsirkan sebagai pelecut kekerasan. Kurban persembahan yang ditolak oleh Allah kemudian ditafsirkan secara salah kaprah oleh Kain sebagai bentuk kebencian Tuhan terhadap dirinya. Padahal, ditolaknya kurban tersebut semata-mata hanya sebuah pengajaran tentang makna ketulusan pengabdian serta tata cara persembahan. Alihalih sadar dengan ihwal demikian, Kain justru terjebak pada identifikasi diri yang keliru; mengambil kesimpulan bahwa ketika Allah tidak menyukai bentuk peribadatan dan agama seseorang, Allah juga tak senang terhadap manusianya. Inilah pemahaman yang selanjutnya menjadi asal mula kekerasan terhadap sesama, pada konteks Kain, ia pun membenci saudaranya, Habel (Schumann, 2015, hal. 490).

Setiap peristiwa kekerasan yang mengatasnamakan teologi agama tertentu dalam penilaian Said Agil Siradj merupakan salah satu bentuk "kecintaan salah kaprah" terhadap keyakinan yang dianut. Hal ini sebagai efek dari tafsir skriptual terhadap teksteks keagamaan. Sehingga, jerat pemaknaan tekstualis ini menjadi faktor pendorong biasnya interpretasi yang pada ujungnya membuahkan aksi-aksi kekerasan dan tindakan desintegratif (Siradj, 2013). Oleh karena itu, gagasan teologi damai yang menempatkan agama sebagai ajaran terbuka, elastis, dan adaptif terhadap aneka tantangan kemajemukan, perlu terus dikembangkan oleh tokoh-tokoh agama selaku aktor kunci agen perdamaian. Sebab, pendidikan agama disinyalir memberikan sumbangsih besar dalam mendorong seseorang untuk mempromosikan, entah perdamaian ataupun kekerasan (Nugroho, 2014). Konsensus teologi universal perspektif agama-agama dengan sendirinya mengikis bibit fanatisme (ashabiyyah); memandang liyan dengan bingkai nalar sesat, bahkan sampai mengkafirkan (Firdausi, 2013).

Penelitian ini mengungkap relasi tokoh agama Islam, Hindu, dan Kristen di Desa Plajan Kecamatan Pakis Aji Kabupaten Jepara dalam mempraktikkan teologi damai. Tidak berhenti sampai di sini, peneliti juga melacak basis argumentasi masing-masing tokoh agama tentang pengejawantahan teologi damai yang bersumber dari doktrin keagamaan, Alasan pemilihan Desa Plajan sebagai lokus penelitian karena interaksi sosial antara elite agama di sana telah terbangun secara harmonis. Strategi komunikasi melalui ajang silaturahmi antar kelompok elite agamawan dianggap menjadi salah satu faktor penting tumbuhnya iklim keteraturan di tengah masyarakat Plajan yang beraneka. Selain Gong Perdamaian Dunia, simbol kerukunan warga Plajan bisa dilihat dari kokohnya tiga bangunan rumah ibadah, yakni masjid, gereja, 
dan pura yang berdiri secara berdekatan. Setiap perayaan hari-hari besar keagamaan dijadikan momentum bagi warga untuk mengejawantahkan laku toleransi. Saat Hari Raya Nyepi, misalnya, umat muslim mengumandangkan azan tanpa menggunakan pengeras suara. Begitu juga ketika Natal maupun Idul Fitri, warga saling berkunjung dari rumah ke rumah sebagai tanda mutual respect. Mengacu kepada fenomena ini, tidak terlalu berlebihan apabila warga Plajan dikategorikan sebagai masyarakat multikultural, yakni komunitas "tercerahkan" yang sadar tentang ragam kehidupan dunia dan menerima fakta keragaman tersebut menjadi sebuah realitas (Azzuhri, 2012).

Pertanyaan penelitian yang diajukan ialah bagaimana persepsi tokoh agama Islam, Hindu, dan Kristen dalam memaknai konsep damai perspektif doktrin agama masingmasing? Bagaimana relasi dan manifestasi teologi damai agama-agama yang ada di sana?

Hal ini penting untuk dijawab, sebab selama ini kajian yang ada di Plajan hanya fokus pada potret kerukunan umat beragama saja, belum ada kajian serius yang mendeskripsikan persepsi tokoh agama tentang kedamaian dilihat dari sudut pandang nilai-nilai teologis. Hasil penelitian ini secara teoretis diharapkan dapat memberikan kontribusi berupa konsepsi teologi perdamaian yang bersumber dari agama Islam, Hindu, dan Kristen. Dalam ranah praktis, penelitian ini mudah-mudahan memberikan suluh positif berupa rekomendasi bagi pegiat perdamaian, khususnya terhadap tokoh agama, agar menebarkan teologi inklusif dalam setiap aktivitas dakwah sosialnya.

\section{Tinjauan Pustaka}

\section{Teologi Damai}

Term teologi, mengacu kepada bahasa Yunani berasal dari kata theos yang berarti Allah atau ilah; dan logos bermakna perkataan; firman; wacana. Sehingga, perspektif terminologis teologi bisa kita artikan menjadi wacana (ilmiah) mengenai Allah atau ilah-ilah (B.F. Drewes dan Julianus Mojau, 2007). Walaupun bersifat wacana, diskursus tentang teologi sangat penting di kalangan teolog, sebab teologi, seperti yang diungkapkan Segundo, merupakan fides quaerens intellectum, yaitu dorongan iman yang mencari pengetahuannya sendiri untuk dapat mengarahkan praksis sejarah (Nitiprawiro, 2008). Jadi, kajian teologi bukan melulu mengulas dimensi normatif ketuhanan, akan tetapi lebih dari itu, berkelindan erat dengan ranah historis kemanusiaan. Bahkan, melalui pemahaman teologis yang komprehensif, seseorang tidak akan mudah diombangambingkan oleh laju perkembangan zaman. Sebab ia mempunyai dalil dan landasan yang sulit dipatahkan (Nasution, 2015).

Meminjam frasa Arab, terma teologi sepadan dengan istilah usul al-din, ilm alkalam, dan 'ilm at-tauhid. Ketiga konsep ini menunjukkan bahwa teologi merupakan diskursus akademik yang mengulas kredokredo agama ('aqa'id) yang bertujuan menunjukkan keesaan dan firman (kalam) Tuhan. Kalam juga bisa dimaknai sebagai kata-kata manusia, pada konteks ini ialah mutakallimin, yaitu teolog Islam yang pandai bersilat lidah dalam mempertahankan argumentasi teologis. Pada ranah substantif, tidak ada seorang pun yang mampu memahami secara "pasti" maksud dari redaksi Kitab Suci. Hanya Tuhan yang benar-benar mengerti kehendak-Nya. Manusia, dengan segenap kemahiran yang dimilikinya, semata-mata berperan sebagai penafsir yang baik. Caranya adalah dengan melibatkan diri dan berinteraksi dengan teks-teks keagamaan, sehingga muatan pesan yang terkandung di balik ayat bisa dimengerti, dicerna, dihayati, bahkan diamalkan. Perbedaan tingkat intelektualitas dan keserbanekaan kedalaman spiritualitas Sang Penafsir meniscayakan kadar pemahaman yang tidak sama. Walaupun obyek ayat Kitab Suci yang dibaca sama, kerap kali memunculkan makna yang berbeda. Mengapa? Identifikasi Alwi Shihab di bawah ini setidaknya cukup membantu kita menyikapi fenomena demikian.

Salah satu sebab yang menimbulkan pemahaman beragam adalah sulitnya dipastikan apakah suatu teks harus dipahami secara literal atau simbolis. Sebab, pada dasarnya, teks-teks keagamaan bagaikan samudera luas dari kata-kata yang terkadang 
diuntai dalam kalimat-kalimat perlambang, dan tidak jarang diungkapkan dalam kata-kata yang mengandung metafor atau makna bersayap. Jelasnya, suatu teks hanya dapat dimengerti kandungannya secara pasti oleh Wujud yang menciptakannya (Shihab, 1999).

Sehingga, wajar saja apabila tidak ada satu pun jenis penafsiran tunggal mengenai redaksi Kitab Suci ketika sudah memasuki domain interpretasi. Boleh jadi bercorak fundamentalis-eksklusif atau progresifinklusif, tekstual atau kontekstual, dan literalis atau metaforis. Semuanya tergantung para agamawan sebagai corong penafsiran.

Dalam penilaian M. Amin Abdullah, kita yang sedang bergelut pada kajian keagamaan, perlu mengintegrasikan dua pendekatan sekaligus, yakni teologis-normatif dan historis-kritis. Sepintas lalu, dua jenis pendekatan ini seringkali hadir dengan watak saling menegasikan, akan tetapi sebenarnya ketegangan tersebut masih dalam taraf yang wajar. Karena, keduanya membentuk satu kesatuan yang utuh, dan kalaupun mengarah kepada hal-hal yang kontradiktif, diharapkan melahirkan ketegangan yang bersifat kreatif (creative tension) yang senafas dengan warna kemajemukan umat beragama di tanah air yang pluralistis (Abdullah, 2015).

Pada konteks berteologi, Amin Abdullah mengklasifikasikan pemikiran teologis menjadi dua corak besar. Pertama, personal commitment dari pemeluk agama terhadap ajaran agama yang diyakininya. Mereka yang mempunyai komitmen kuat terhadap doktrin agama yang dianut, tentu akan berjuang mati-matian mempertahankannya.

Jika perlu, mereka akan mengorbankan tenaga, pikiran, hata benda, lebih-lebih nyawa. Kedua, "bahasa" yang digunakan oleh pemeluk agama terkait erat dengan bahasa seorang "aktor" atau pelaku agama. Sifatnya internal, mempribadi, dan subyektif. Berbeda dengan bahasa pengamat atau peneliti yang memperlakukan agama sebagai obyek studi ilmu pengrtahuan, sehingga memegang prinsip-prinsip kaidah ilmiah yang logis, rasional, dan obyektif. Posisi pengamat tak ubahnya jadi penonton (spectator) yang dengan sertamerta menjaga jarak terhadap obyek studi yang ditekuninya. Bagi Amin, mengutip pendapat Ian G. Barbour, pakar Hubungan Sains dan Agama dari Amerika, seorang agamawan, terlepas dari apapun agamanya, senantiasa menunjukkan perilaku konsisten dan mau menderita ketika mempertahankan ajaran-ajaran doktriner agamanya (Abdullah, 2015, hal. 50). Jika tidak waspada, agamawan akan terperangkap pada jerat klaim kebenaran tunggal (truth claim).

Kadang kita terlalu percaya diri, menganggap jalan kita saja yang paling absah untuk mencapai kehendak Tuhan. Sebagai muslim, contohnya, kita tak lelah menggembar-gemborkan bahwa Islam adalah satu-satunya agama yang paling benar. Selain Islam salah. Islam lah yang paling lurus. Di luar Islam, melenceng. Islam juga yang paling bisa dijadikan garansi untuk mengkapling surga. Sementara agama lain kekal di neraka. Akhirnya, kita selalu memoles wajah agama dengan aksesoris-aksesoris kebencian. Dengan menghina agama lain, berarti kita sedang memuliakan agama kita. Mencaci Injil sama juga kita mengangkat harkat Al-quran. Memusuhi pendeta sebelas dua belas dengan mencintai kiai. Begitu kira-kira cara pandangnya.

Kerangka paradigma dikotomi di atas, ketika muncul pada masyarakat heterogen meletupkan spirit kompetisi destruktif yang berkecenderungan melahirkan disharmoni sosial. Secara kasat mata, boleh jadi karakteristik konflik yang terjadi masih bersifat laten. Akan tetapi, jika fanatisme, etnosentrisme, dan stereotip yang dibumbui sentimen agama dibiarkan begitu saja, bukan tidak mungkin lambat laun bermetamorfosis menjadi konflik manifes.

Ujungnya ialah disintegrasi (Purwasito, 2015). Oleh karena itu, mengutip apa yang disampaikan oleh Purwasito, lapisanlapisan elite masyarakat, khususnya tokoh agama, perlu mentradisikan komunikasi multikultural untuk mereduksi ragam kesalahpahaman. Sehingga, masyarakat dapat hidup berdampingan secara damai dalam bingkai harmonisasi (peacefull coexitence) (Purwasito, 2015, hal. 64). 


\section{METODE PENELITIAN}

Penelitian ini bisa dikategorikan dalam jenis penelitian lapangan (field research) melalui pendekatan qualitative research. Dari segi metode, penelitian ini termasuk penelitian kasus (case study). Adapun kasus yang menjadi bahan studi dalam penelitian ini adalah relasi, persepsi, dan manifestasi tokoh agama Islam, Hindu, dan Kristen mengenai teologi damai yang menempatkan ajaran agama sebagai alat perdamaian.

Dalam proses pengumpulan data, peneliti menggunakan teknik observasi peran serta, wawancara mendalam, dan dokumentasi. Observasi peran serta dilakukan untuk menyelami persepsi tokoh agama Islam, Hindu, dan Kristen tentang konsep perdamaian perspektif agama. Sedangkan wawancara dilakukan dengan berdialog langsung dengan aktor-aktor kunci seperti agamawan Islam (kiai atau ustad), Kristen (pendeta atau tokoh agama Kristen), dan agamawan Hindu selaku agen perdamaian. Wawancara difokuskan pada penggalian data tentang relasi antara masing-masing tokoh agama dan manifestasi teologi damai. Supaya data penelitian yang akan digali lebih variatif, maka teknik dokumentasi menjadi alternatif ketiga yang dipakai oleh peneliti. Secara teknis, dokumentasi dilakukan dengan menelusuri dokumen-dokumen terkait baik berupa catatan, foto, atau artikel tentang manifestasi teologi damai di desa Plajan.

Semua data yang diperoleh kemudian dianalisis dengan menggunakan teknik analisis deskriptif dengan menggunakan pendekatan fenomenologi. Adapun langkah-langkahnya meliputi reduksi data, dilanjutkan penyajian data, lalu diakhiri dengan penarikan kesimpulan dan verifikasi. Untuk menguji keabsahan dan kredibilitas hasil penelitian diguanakan dua cara. Pertama, memperpanjang pengamatan dengan melakukan pengujian terhadap data, apakah data yang diperoleh setelah dicek ke lapangan benar atau tidak, berubah atau tidak. Bila setelah dicek ternyata benar, berarti data kredibel dan perpanjangan observasi bisa diakhiri. Kedua, melakukan pemeriksaan dengan membaca ulang hasil wawancara, apakah sudah mendalam atau belum, sesuai dengan tujuan ataukah belum. Bila perlu, peneliti melakukan wawancara ulang atau konfirmasi kepada narasumber pada waktu yang berbeda.

\section{PEMBAHASAN} Relasi Tokoh Agama Islam, Hindu, dan
Kristen di Desa Plajan

Plajan merupakan desa multikultural yang terletak di Kecamatan Pakis Aji Kabupaten Jepara. Desa yang terdiri dari 43 RT, 7 RW, dan 24 dukuh ini memiliki kultur toleransi yang khas. Dari 8.056 jiwa penduduknya, Islam menjadi agama dominan yang dipeluk oleh 7.551 orang $(93,73 \%)$, Kristen 53 orang $(0,66 \%)$, Hindu 448 orang $(5,56 \%)$, dan Buddha 4 orang $(0,05 \%)$.

\begin{tabular}{llll}
\hline No & Agama & Jumlah & Prosentase \\
\hline 1 & Islam & 7.551 & 93,73 \\
2 & Kristen & 53 & 0,66 \\
3 & Hindu & 448 & 5,56 \\
4 & Buddha & 4 & 0,05 \\
Jumlah Total & & 8.056 & 100 \\
\hline
\end{tabular}

Tabel. 1 Jumlah Penduduk Menurut Agama di Desa

Plajan, Sumber: Profil Desa Plajan, 2018

Ekspresi budaya damai di Plajan, sebagaimana dalam kultur masyarakat Jawa pada umumnya, tidak bisa dilepaskan dari peran elite agama, yang oleh Geertz difungsikan sebagai, cultural broker (Geertz, 1960). Tokoh agama mempunyai posisi strategis untuk menghubungkan masyarakat kelas bawah dengan kelompok elite lokal yang menempati puncak hierarki sosial. Dengan begitu, agamawan bisa dengan leluasa menyisipkan ajaran-ajaran damai yang mampu mendorong umat beragama untuk bersikap toleran dan saling menghormati (Qodir, 2016).

Potret relasi sosial keagamaan yang harmonis antar pemeluk agama telah berjalan lama di Desa Plajan Kecamatan Pakis Aji Kabupaten Jepara Jawa Tengah. Strategi komunikasi melalui ajang silaturahmi antar kelompok elite agamawan dianggap menjadi salah satu faktor penting tumbuhnya iklim 
keteraturan di tengah masyarakat Plajan yang beraneka. Dengan cara komunikasi kelompok, masing-masing umat beragama di Plajan, yaitu Islam, Kristen, dan Hindu, satu sama lain saling mengeratkan persaudaraan (Ma'arif, 2015).

Melalui visi "Terwujudnya Desa Plajan yang Religius, Damai, Maju, Profesional, Proporsional, dan Sejahtera Lahir Batin yang Berpijak pada Potensi Budaya Lokal", Pemerintah Desa Plajan berusaha menumbuhkan iklim perdamaian pada masyarakat melalui kebijakan inklusif. Hal ini sebagaimana pengakuan Kepala Desa Plajan (Petinggi) dalam kesempatan wawancara dengan peneliti pada Rabu, 24 April 2019 di Balai Desa Plajan."Pada APBDes 2017/2018, saya mengalokasikan anggaran buat lembagalembaga agama di desa. Semuanya tanpa terkecuali. Meskipun besarnya tidak seberapa. Tapi lumayan untuk mendukung kegiatan keagamaan mereka." (Priyatin, 2019).

Pada momentum perayaan hari-hari besar keagamaan, Pemerintah Desa Plajan juga aktif membangun atmosfer perdamaian.

Pada saat Nyepi, saya membuat surat himbauan dari desa agar umat Islam tidak menggunakan pengeras suara di masjid atau mushalla yang dekat dengan Pura. Tidak boleh nyetel tip banter-banter (menyalakan tape dengan suara keras). Pasukan Disiplin Masyarakat (Linmas) di sekitar Pura juga dihimbau untuk menjaga perayaan Nyepi. Ini sudah berlangsung sejak Pak Marwoto (Alm.) menjabat jadi Petinggi sekitar tahun 1998 (Priyatin, 2019).

Paparan dari Petinggi Plajan tersebut diperkuat oleh surat resmi yang dikeluarkan oleh Pemerintah Desa tanggal 04 Maret 2019 Nomor 535/15 perihal himbauan terhadap gangguan keamanan dan ketertiban Hari Raya Nyepi 2019. Di antara isinya ialah memohon sikap toleransi dari umat Islam dan umat Kristiani atas gangguan keamanan dan ketertiban selama berlangsungnya kegiatan Brata Nyepi. Mereka dihimbau untuk menjaga kondusivitas ritual Nyepi dengan cara tidak membunyikan pengeras suara dan tidak membuat suasana gaduh pada lokasi sekitar pura. Tujuannya tidak lain ialah mengokohkan bangunan perdamaian antar umat beragama.

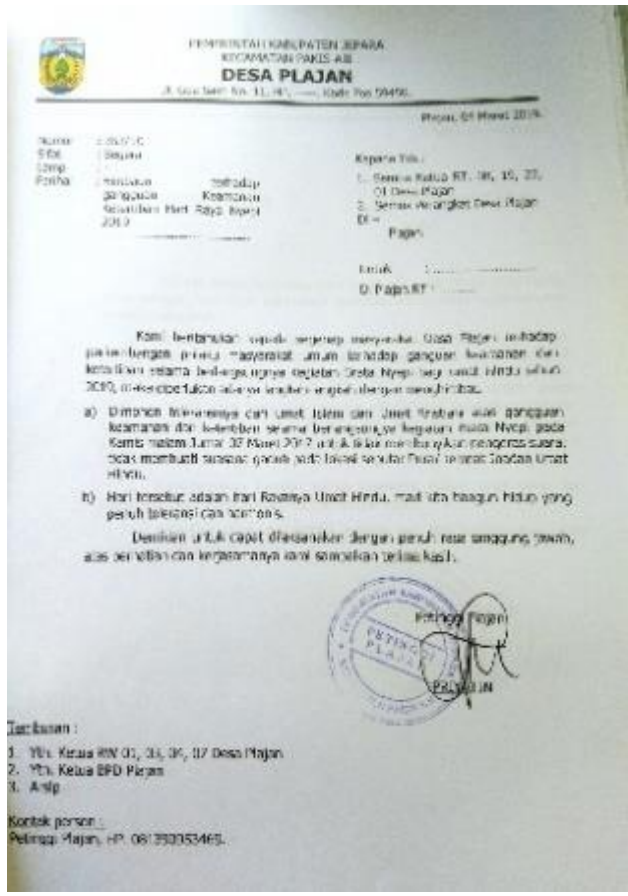

Gambar 1. Surat Himbauan Menjaga Keamanan dan Ketertiban Selama Hari Raya Nyepi. Sumber: Dokumen Pemerintah Desa Plajan, 2019

Setelah mendapatkan informasi dari Ibu Priyatin selaku Petinggi Plajan, peneliti kemudian menemui beberapa informan lain. Di antaranya ialah Bapak Karjani, sosok yang pernah menjabat sebagai Ketua Majlis Gereja di Plajan selama 3 periode ( 9 tahun). Meskipun sekarang sudah demisioner, tapi informan ini sangat membantu peneliti dalam mengungkap data tentang intreraksi warga Kristen dengan agama lain di Plajan. Pada kesempatan itu, Bapak Karjani ditemani oleh Ibu Suyat, istrinya. Menurutnya, ekspresi budaya damai di Plajan juga tergambar dari bersatunya makam penduduk. Siapapun yang meninggal dunia, tidak ada perbedaan perlakuan. Semuanya dimakamkan di Makam Tri Tunggal. Filosofi Tri Tunggal ialah satu makam yang dihuni oleh tiga agama yang ada di Plajan, yaitu Islam, Hindu, dan Kristen,

Wong Plajan niku sae. Rukun sedanten. Wong makam mawon dados setunggal. Kangge agama Islam, Kristen, kaleh Hindu (Orang Plajan itu baik. Rukun semuanya. Makam saja jadi satu. Buat agama Islam, Kristen, dan Hindu (Karjani, 2019). 
Meskipun pihak desa telah berupaya memfasilitasi kegiatan-kegiatan yang sifatnya inklusif, akan tetapi jika ditelisik lebih dalam, belum sepenuhnya memberikan kesempatan kepada tokoh lintas agama untuk berinteraksi dalam satu forum. Masing-masing agama melakukan kegiatan secara terpisah-pisah dan hanya dihadiri oleh sesama pemeluk agamanya.

Di Plajan hampir selalu diadakan doa bersama pada akhir tahun menjelang awal tahun. Dilaksanakan selama tiga malam berturut-turut sesuai dengan jumlah agama yang ada di sini. Misalnya, malam pertama umat Islam, malam selanjutnya Kristen, dan diakhiri Hindu (Priyatin, 2019).

Relasi damai yang terjalin antaragama di Desa Plajan ini juga diamini oleh Ngardi, agamawan Hindu Plajan yang juga menjadi angggota Forum Kerukunan antar Umat Beragama (FKUB) Kabupaten Jepara. Seingatnya, belum pernah terjadi kasus kekerasan yang melibatkan warga dengan membawa sentimen agama, isu mayoritasminoritas, dan politik identitas.

Respons masyarakat (kepada umat Hindu) baik, karena sama-sama merasa damai. Acara kematian agama apapun saling menghadiri. Makam juga jadi satu. Saat Nyepi, pasti didukung oleh Banser dengan cara menjaga dan mengawal upacara Melasti sampai Pantai Bandengan. Idul Fitri, pemuda Hindu Jogo Boyo ikut melakukan pengamanan di sekitar masjid dan lapangan (Ngardi, 2019).

Berdasarkan hasil wawancara dari pelbagai informan, baik Islam, Hindu, maupun Kristen, relasi damai, pada konteks ini, masih diartikan oleh mereka secara pasif. Jika tidak ada pertikaian, maka sudah dianggap damai. Padahal, istilah perdamaian melibatkan unsurunsur aktif. Misalnya, tokoh lintas agama bisa dengan leluasa saling berinteraksi tanpa dibayang-bayangi rasa takut, canggung, atau dalam istilah Jawa ewoh pakewoh. Jadi, meskipun tidak ada konflik yang manifes, kalau antar tokoh agama masih bersikap eksklusif, hanya berkomunikasi dengan sesama pemeluk agamanya, maka belum bisa dikatakan damai. Sebab damai itu tidak sekadar koeksistensi tapi juga proeksistensi.

\section{Persepsi dan Manifestasi Teologi Damai Agama-Agama di Desa Plajan}

Alquran sebagai kitab suci umat Islam, secara tersurat maupun tersirat sangat menjunjung tinggi budaya damai, mulai dari ruang lingkup keluarga (al-Nisa: 128), masyarakat multikultural (al-Maidah: 48), antar umat beragama (al-Baqarah: 256), hingga perdamaian dalam kondisi peperangan sekalipun (al-Anfal: 61) (Halim, 2014). Nilainilai perdamaian juga tampak dari ajaran mewujudkan persatuan dan kesatuan umat (alMukminûn: 52), anjuran bermusyawarah dalam penyelesaian konflik sosial dan politik (al-Syûrâ: 38; Âli Imrân: 159), keharusan untuk mendamaikan pertikaian antar kelompok (al-Hujurât: 9), kewajiban mempertahankan kedaulatan Negara, larangan melakukan tindakan agresi dan invasi (alBaqarah: 190), mengutamakan perdamaian daripada aspek permusuhan (al-Anfâl: 61), mementingkan perdamaian bangsa-bangsa (alHujurât: 13), dan menumbuhkan sikap kewaspadaan dalam bidang pertahanan dan keamanan (al-Anfâl: 60) (Ritaudin, 2011). Islam juga menekankan sikap inklusivitas, toleransi dan penghormatan terhadap realitas kemajemukan agama dan keyakinan seperti yang termaktub dalam Surat al-Kafirun (Udin, 2016).

Doktrin teologi damai yang demikian ini senantiasa melekat dalam persepsi masyarakat Muslim di Plajan. Persepsi ini kemudian dimanifestasikan dalam laku keseharian mereka ketika berinteraksi dengan agama lain. Hal ini tampak dari ungkapan Priyatin, selaku informan penelitian berikut:

$$
\text { Damai itu ketika tidak ada }
$$
permasalahan. Seluruh warga saling menghormati dan setiap ada masalah bisa diselesaikan secara baik. Tidak ada gesekan. Di sini, setiap Natalan, ada Banser dan Linmas dari umat Islam yang menjaga. Saat Shalat Idul Fitri atau Idul Adha, orang Hindu juga ikut menjaga. Ada pasukan pengamanan yang namanya Jogo Boyo. Sebaliknya, saat ritual Melasti ke pantai Bandengan, Banser NU gantian yang mengawal. Itu semua atas kesadaran masyarakat. (Priyatin, 2019).

Khusus bagi warga Nahdlatul Ulama (NU) Ranting Desa Plajan, perwujudan budaya 
damai ini tidak lepas dari peran struktural NU tingkat kabupaten yang selalu memberikan instruksi lisan untuk berpartisipasi dalam setiap kegiatan-kegiatan perayaan agama di luar Islam. Setidaknya terdapat tiga instruksi penting, yakni pelarangan penggunaan pengeras suara bagi warga NU Plajan saat perayaan Nyepi, keharusan Banser NU mengawal Upacara Melasti, dan penjagaan gereja tatkala umat Kristen merayakan Natal. Melasti adalah upacara pensucian diri yang dilakukan oleh seluruh warga Hindu Plajan menjelang perayaan Nyepi. Dilacak dari akar katanya, Melasti berasal dari kata Mala yang bermakna kotoran/leteh, dan Asti yang berarti membuang/memusnahkan. Ritual Melasti dilaksanakan pada tiga atau dua hari sebelum perayaan Nyepi (Noviasih, 2013). Tradisi yang biasa berjalan, warga Hindu Plajan melaksanakan kegiatan larung sesaji, yaitu dengan cara menghanyutkan hasil bumi dan bebek ke tengah laut Bandengan Jepara sebagai tanda syukur dan bentuk penyucian diri kepada Tuhan.

Ada instruksi lisan dari Mbah Yatun (Ketua Tanfidziyah PCNU Kabupaten Jepara); dilarang membunyikan pengeras suara, Banser harus mengawal Melasti, dan menjaga gereja (Tupomo, 2019).

Hampir senada dengan pandangan Priyatin, persepsi damai menurut Karjani, Tokoh Agama Hindu di Desa Plajan, ialah suasana kehidupan yang rukun, harmonis, dan tak ada pertikaian antar warga. "Damai niku nggeh rukun. Mboten cekcok. Guyub karo tonggo (damai itu, ya rukun. Tidak bertikai. Menghindari pertengkaran dengan tetangga)" (Karjani, 2019). Perspektif teologi agama Hindu, Tuhan adalah entitas transenden yang tidak terbatas dan mustahil bisa dijangkau oleh akal manusia yang terbatas. Sehingga, Tuhan tak mungkin diserupakan dengan apapun. Doktrin spiritual yang umumnya dianut oleh elite agama Hindu seperti $r s i$, yogi atau para sufi ini kemudian populer dengan sebutan Teologi Nirguna Brahman. Sedangkan teologi orang Hindu yang masih menduduki level awam diistilahkan dengan Teologi Saguna Brahman yang membolehkan manusia untuk berimajinasi tentang eksistensi Tuhan Yang Tak Terbayangkan. Dari konsepsi teologis inilah selanjutnya memunculkan simbolsimbol keagamaan Hindu sebagai manifestasi Tuhan di dunia yang memungkinkan untuk bisa dinalar oleh manusia (Donder, 2015). Filosofi simbol patung, misalnya, oleh Sumiat, salah seorang tokoh agama Hindu di Plajan, tidak lain sebatas medium perantara yang menjembatani hubungan antara manusia dengan Tuhan.

Manusia terlalu kotor jika harus berhadapan langsung dengan Tuhan. Patung itu untuk memudahkan manusia dalam berkomunikasi dengan Tuhan. Patung itu personifikasi dan simbol. Lambang minangka ajaran, ajaran minangka lambang (lambang ibarat ajaran, ajaran ibarat lambang) (Sumiat, 2019).

Berdasarkan hasil wawancara dengan Parsini, salah satu tokoh agama Hindu, Teologi damai umat Hindu Plajan tercermin dari konsep tat twam asi yang memiliki makna kamu adalah saya, saya adalah kamu. Sehingga, orang Hindu tidak diperkenankan melakukan kekerasan dalam bentuk apapun. "nek aku kok jiwit lara, kowe ojo njiwit aku; Jika saya dicubit merasa sakit, maka kamu tidak boleh mencubit." (Parsini, 2019). Dasar agama Hindu adalah karma. Manusia diberi dua jalan oleh Tuhan; positif dan negatif. Agama berfungsi memberikan batasan-batasan normatif. Namun, pada akhirnya diserahkan sepenuhnya kepada manusia.

Pada aspek toleransi, umat Hindu menghindari nalar truth claim; mengaku agama sendiri yang paling benar. Masih menurut pengakuan Parsini, orang lain yang tidak seagama dengannya begitu dihormati.

Dalam Hindu, orang yang sudah beragama tidak boleh diajak ke agama Hindu. Cung taka istilahnya. Jika ada orang yang sudah memeluk agama tertentu, kemudian diajak ikut Hindu, yang mengajak mendapatkan dosa besar. Kita tidak pernah mengaku kalau Hindu itu benar sendiri (Parsini, 2019).

Teologi damai berikutnya dalam agama Hindu ialah vasudhaiva kutumbakam, sebuah doktrin yang meyakini bahwa manusia di seluruh dunia merupakan satu keluarga tunggal. Ajaran Hindu memandang terma persaudaraan melampaui sekat agama. 
Sebagaimana penuturan Edi, Pemuda Hindu Plajan, berikut ini:

Kita semua adalah saudara tanpa memandang bulu. Vasudhaiva kutumbakam. Semua ciptaane Gusti. Damai dalam diri kita belum tentu damai bagi orang lain. Damai hakikatnya datang dari dalam pribadi kita sendiri. Kalau ada provokator dari pihak luar, sedangkan kita gak damai, pasti akan ikut terprovokasi (Edi, 2019).

Edi juga memaparkan bahwa esensi kedamaian menurut umat Hindu direpresentasikan dalam penutup salam yang sering diucapkan dalam pelbagai forum-forum pertemuan resmi, "om shanti shanti shanti om." Om adalah simbol Tuhan dan shanti bermakna damai. Ucapan shanti yang pertama secara filosofis dimaksudkan sebagai bentuk pengharapan damai di hati manusia. Shanti yang kedua merujuk kepada arti damai bagi seluruh makhluk hidup di dunia. Shanti ketiga merupakan doa kedamaian bagi manusia selama-lamanya. Begitu pula dalam kata sapaan salam, "óm swastyastu" yang berarti semoga semua makhluk dalam keadaan bahagia. Edi kembali menegaskan kepada peneliti, frasa yang digunakan ialah sетиa makhluk, bukan mendoakan orang Hindu saja (Edi, 2019).

Narasi-narasi kedamaian dari tokoh agama Islam dan Hindu di atas tidak dibantah oleh tokoh agama Kristen. Bahkan, seperti yang diungkapkan oleh Rustanto, salah satu guru Sekolah Mingu di Gereja Kristen Muria Indonesia (GKMI) Mlonggo Cabang Plajan saat diwawancarai oleh peneliti, semua agama, tidak terkecuali Kristen, hakikatnya meneruskan risalah damai melalui utusan Tuhan yang terpilih. "Semua agama mengajarkan perdamaian. Kasihilah sesama manusia seperti kamu mengasihi dirimu sendiri. Gusti Allah dhewe seng mudun neng ndunya, njelma dadi menungsa kanggo nebus dosa (Allah sendiri yang turun ke dunia menjelma jadi manusia untuk menebus dosa)" (Rustanto, 2019).

Damai, baginya, bisa terwujud melalui tiga tindakan integral yang tidak bisa dipisahkan. Pertama, harus mampu hidup rukun dengan Tuhan Sang Pencipta. Kedua, hidup berdampingan dengan orang lain, termasuk mereka yang memusuhi kita. Ketiga, harus bisa berdamai dengan alam sekitar. Ia menjelaskan:

Kasihilah musuhmu! Nek mata ganti mata (Kalau mata harus dibalas dengan mata), maka dunia gelap semua. Nek bales-balesan (jika saling membalas), maka konflik gak akan ada habisnya. Yang susah itu kalau pemahamannya sudah salah, yang beda dianggap musuh (Rustanto, 2019).

Ketika peneliti berusaha mengelaborasi teologi damai Kristen versi Alkitab, Rustanto menyarankan kepada peneliti agar menemui Pendeta Sumihar Tambunan selaku penggembala jemaat di Desa Plajan. Akhirnya, peneliti berhasil menemuinya di rumah dinas GKMI Mlonggo Jepara. Hasil wawancara dengannya menyimpulkan bahwa setidak-tidaknya, ada dua ayat Alkitab yang secara eksplisit mengajarkan teologi damai kepada umat Kristiani. Yaitu Matius 5:39, "Tetapi Aku berkata kepadamu: Janganlah kamu melawan orang yang berbuat jahat kepadamu, melainkan siapapun yang menampar pipi kananmu, berilah juga kepadanya pipi kirimu,"; dan juga Matius 7:12, "Segala sesuatu yang kamu kehendaki supaya orang perbuat kepadamu, perbuatlah demikian juga kepada mereka." Ayat pertama mengajak kepada umat Kristen untuk senantiasa rendah hati dan menjauhi watak pendendam. Sedangkan ayat kedua merupakan seruan damai dan saling menyayangi kepada siapapun dan di level manapun, mulai lingkup keluarga, sekolah, dan masyarakat umum. Menurut Sumihar, damai harus dimaknai sebagai tindakan aktif, bukan pasif. "Damai itu bukan berarti semua tenang. Tapi bagaimana kita bisa menggeluti konflik dan mentransformasikannya menjadi alat perdamaian (Tambunan, 2019). Sumihar juga mencontohkan manifestasi damai dalam kehidupan masyarakat yang majemuk.

Misalnya saya disakiti, saya sebagai orang Batak harusnya emosional. Misal ada orang yang berkata, "Bapak sebagai Pendeta kan belum berbuat apa-apa." Saya tidak balas. Saya menahan diri. Orang yang sudah menerima Tuhan jadi juru selamatnya, maka hidupnya harus bermetamorfosis. Harus jadi 
baik. Ada juga jemaat yang ingin semaunya untuk melakukan penginjilan. Saya bilang, "hati-hati! Boleh semangat, tapi jangan sampai kehilangan hikmat. (Tambunan, 2019).

\section{PENUTUP}

Relasi sosial keagamaan di Desa Plajan terjalin harmonis melalui peran tokoh agama. Media silaturahmi antar kelompok elite agamawan merupakan salah satu faktor penting berkembangnya praktik teologi damai. Meskipun, damai dalam konteks ini masih dimaknai secara pasif; tidak ada pertikaian, sama artinya dengan damai. Padahal, implementasi teologi damai seyogyanya melibatkan keaktifan tokoh lintas agama. Sehingga, mereka bebas berinteraksi dengan umat apapun dengan tidak disertai ewoh pakewoh. Apabila kondisi ini mampu terwujud, damai tak lagi sebatas proses koeksistensi, akan tetapi jauh melebar ke ranah proeksistensi.

Atmosfer keharmonisan antaragama di Plajan tidak lepas dari kontribusi pemuka agama dalam "membumikan" teologi perdamaian. Bagi orang Islam, teologi damai tersebut mengacu kepada doktrin Alquran, misalnya QS. al-Baqarah: 256 yang mengajarkan setiap muslim untuk saling menghormati dan respect terhadap umat agama lain. Setiap ada persoalan, sebisa mungkin diselesaikan dengan baik. Bentuk pengejawantahan dari teologi damai ini berupa penjagaan gereja atau Pura oleh Banser NU ketika umat Kristen merayakan Natal. Begitu juga saat umat Hindu merayakan Nyepi. Bahkan, Kepala Desa yang notabene muslim membuat surat himbauan agar umat Islam tidak menggunakan pengeras suara di masjid atau mushalla yang dekat dengan Pura. Saat ritual Melasti ke Pantai Bandengan, Banser NU juga berinisiatif melakukan pengamanan.

Perspektif Hindu, teologi damai direpresentasikan oleh ajaran tat twam asi, cung taka, vasudhaiva kutumbakam, om shanti shanti shanti om, dan óm swastyastu. Manifestasi dari teologi damai tat twam asi meliputi larangan bertikai, menghindari pertengkaran dengan tetangga, dan jika dicubit merasa sakit, maka tidak boleh mencubit orang lain. Cung taka menyeru kepada umat Hindu untuk menghindari nalar truth claim; mengaku agama sendiri yang paling benar. Sehingga, pada saat Shalat Idul Fitri atau Idul Adha, orang Hindu juga ikut menjaga masjid tanpa harus merasa kualitas keimanannya terdistorsi. Vasudhaiva kutumbakam mewanti-wanti supaya orang Hindu tidak mudah terpancing provokasi. Om shanti shanti shanti om diejawantahkan dengan berusaha menciptakan iklim perdamaian mulai dari hati (diri sendiri), manusia lain, dan seluruh makhluk hidup. Adapun penerapan óm swastyastu melalui kegiatan doa bersama, bukan mendoakan orang Hindu saja.

Sedangkan teologi damai agama Kristen tampak dari penjelasan Matius 5:39 dan Matius 7:12. Keduanya dimanifestasikan oleh umat Kristen di Plajan dengan cara bersikap rendah hati terhadap agama lain, menjauhi watak pendendam, menjaga masjid saat umat muslim menunaikan shalat Idul Fitri dan Idul Adha, saling menyayangi kepada siapapun dan di level manapun, mulai lingkup keluarga, sekolah, dan masyarakat umum.

\section{UCAPAN TERIMA KASIH}

Pada kesempatan ini, peneliti berterima kasih kepada beberapa pihak. Di antaranya yaitu Direktorat Jenderal Penguatan Riset dan Pengembangan Kementerian Riset, Teknologi, dan Pendidikan Tingggi (DRPM Ristek Dikti) yang telah membiayai sepenuhnya skema Penelitian Dosen Pemula (PDP) tahun anggaran 2018/2019. Tidak lupa, peneliti juga berhutang budi kepada Lembaga Penelitian dan Pengabdian kepada Masyarakat (LPPM) Universitas Islam Nahdlatul Ulama (Unisnu) Jepara yang telah memberikan rekomendasi penelitian di Desa Plajan dengan judul "Peran Tokoh Agama dalam Membangun Budaya Damai Melalui Pendidikan Active Non-Violence". Terakhir, peneliti berterimakasih kepada Pemerintah Desa Plajan Kecamatan Pakis Aji Kabupaten Jepara dan segenap tokoh agama Islam, Hindu, dan Kristen di sana yang sangat kooperatif dalam proses penggalian data penelitian. 


\section{DAFTAR PUSTAKA}

Abdullah, M. Amin. 2015. Studi Agama: Normativitas atau Historisitas? Yogyakarta: Pustaka Pelajar.

Azzuhri, Muhandis. 2012. 'Konsep Multikulturalisme dan Pluralisme dalam Pendidikan Agama'. FORUM TARBIYAH.

B.F. Drewes dan Julianus Mojau. 2007. Apa itu Teologi? : Pengantar ke dalam Ilmu Teologi. Jakarta: BPK Gunung Mulia.

Donder, I. Ketut. 2015. 'Keesaan Tuhan dan Peta Wilayah Kognitif Teologi Hindu: Kajian Pustaka tentang Pluralitas Konsep Teologi dalam Hindu'. Harmoni: Jurnal Multikultural \& Multireligius.

Edi. 2019. Teologi Damai Perspektif Hindu. (A. Saefudin, Pewawancara)

Firdausi, M. Anwar. 2013. 'Teologi Universal: Solusi mencegah kekerasan Berlatar Agama'. Ulul Albab.

Geertz, Clifford. 1960. 'The Javanese Kijaji: the Changing Role of a Cultural Broker'. Comparative Studies in Society and History.

Halim, Abd. 2014. 'Budaya Perdamaian dalam Al-Qur'an'. Jurnal Studi Ilmu-Ilmu alQur'an dan Hadis.

Karjani. 2019. Budaya Damai di Desa Plajan Perspektif Kristen. (A. Saefudin, Pewawancara)

Ma'arif, Syamsul. 2015. 'Strategi Komunikasi Antar Umat Beragama dalam Menumbuhkan Ukhuwwah Wathaniyyah di Desa Plajan Kecamatan Pakis Aji Kabupaten Jepara'. Jurnal AnNida.

Mustaqim, Abdul. 2014. 'Konflik Teologis dan Kekerasan Agama Dalam Kacamata Tafsir Alquran'. Episteme.

Nasution, Harun. 2015. Teologi Islam: AliranAliran, Sejarah Analisa, dan Perbandingan. Jakarta: Penerbit Universitas Indonesia (UI-Press).

Ngardi. 2019. Relasi Umat Hindu dengan Islam. (A. Saefudin, Pewawancara)

Nitiprawiro, Francis Wahono. 2008. Teologi Pembebasan: Sejarah, Metode, Praksis, dan Isinya. Yogyakarta: LKiS.
Noviasih, Ni Kadek Putri. 2013. Makna Hari Raya Nyepi. Artikel dipublikasikan dan dikutip dari http://sulut. kemenag. go. id/file/file/BimasHindu/qcgw13675265 50. pdf. Diakses pada 16 (2016).

Nugroho, Oktavianus Heri Prasetyo. 2014. Meretas Damai di Tengah Keberagaman: Mengembangkan Pendidikan Kristiani untuk Perdamaian dalam Perspektif Multikulturalisme. GEMA TEOLOGI.

Parsini. 2019. Teologi Damai Perspektif Hindu. (A. S. Rohman, Pewawancara)

Priyatin. 2019. Kebijakan Inklusif Pemerintah Desa Plajan. (A. Saefudin, Pewawancara)

Purwasito, Andrik. 2015. Komunikasi Multikultural. Yogyakarta: Pustaka Pelajar.

Qodir, Zuly. 2016. 'Kaum Muda, Intoleransi, dan Radikalisme Agama'. JURNAL STUDI PEMUDA.

Ritaudin, M. Sidi. 2011. 'Damai di Tengah Masyarakat Multikultur dan Multiagama'. Al-AdYaN.

Rustanto. 2019. Teologi Damai Perspektof Kristen. (A. Saefudin, Pewawancara)

Schumann, Olaf Herbert. 2015. AgamaAgama: Kekerasan dan Perdamaian. Jakarta: Gunung Mulia.

Shihab, Alwi. 1999. Islam Inklusif: Menuju Sikap Terbuka dalam Beragama. Bandung: Penertbit Mizan.

Siradj, Said Agil. 2013. 'Menggagas Teologi Perdamaian Sunni-Shi'ah di Indonesia'. Teosofi: Jurnal Tasawuf dan Pemikiran Islam.

Sumiat. 2019. Budaya Damai Perspektif Hindu. (A. S. Rohman, Pewawancara)

Tambunan, Sumihar. 2019. Teologi Damai Perspektif Kristen. (A. S. Rohman, Pewawancara)

Tupomo. 2019. Budaya Damai di Plajan Perspektif Islam. (A. Saefudin, Pewawancara) Jepara.

Udin, Nur Hidayat Wakhid. 2016. 'Truth Claim dan Implikasinya dalam Penciptaan Kohesi Damai Antarumat Beragama'. ISLAMICA: Jurnal Studi KeIslaman. 
